\title{
A Comparative Analysis of Short Time Series Processing Methods
}

\author{
Arnis Kirshners ${ }^{1}$, Arkady Borisov ${ }^{2},{ }^{1-2}$ Riga Technical University
}

\begin{abstract}
This article analyzes the traditional time series processing methods that are used to perform the task of short time series analysis in demand forecasting. The main aim of this paper is to scrutinize the ability of these methods to be used when analyzing short time series. The analyzed methods include exponential smoothing, exponential smoothing with the development trend and moving average method. The paper gives the description of the structure and main operating principles. The experimental studies are conducted using real demand data. The obtained results are analyzed; and the recommendations are given about the use of these methods for short time series analysis.
\end{abstract}

Keywords - short time series, forecasting, exponential smoothing, exponential smoothing with the development trend, moving average method

\section{INTRODUCTION}

Usually, when analyzing demand data that are considered time series and represent the historical market demand for the product in a given period of time, there is a necessity for forecasting - to determine the possible product demand in the future. Accurate forecasts can reduce the decision risks, which emerge, e.g. when the necessary number of the product is ordered for the next sales cycle.

Traditionally, the process of the time series analysis is based on searching for patterns in a long period of time by analyzing the changes of values in moments of time; as a result the future values of the analyzed object are extrapolated. Such processes can be related to changes of economic indexes, e.g. currency exchange rate fluctuations [1]. Similar processes are analyzed in tourist inflow forecasting for the next season [2]. All these analysis processes are similar as the changes in environment functionality cause the changes in the parameters. It is postulated that a time series is stationary; the longer the period of monitoring is in this time series, the greater the probability is to find these patterns more effectively [3].

The current market demand for the product, when the demand depends on the price, can be determined using regression analysis [4], directing it by sales capacity statistics. This approach can be used only for market analysis; it does not give information about the possible demand in the future. The forecasts have to contain both external and internal factors that can influence the environment. The external factors can be related to the standard of living of the population (taxes, income etc.), political and social situation, climatic conditions, world currency rate fluctuations, etc. The internal factors, on the other hand, are related to the price, quality, advertisement campaigns, trademark popularity, etc. of the goods manufacturer, seller or the middleman. The goal of forecasting is to reduce the effect of random factors on the resulting situation as adequately as possible, as well as help the decision maker choose the right strategy while making the decision. The credibility of the forecasting results is greatly affected by the accurate selection of the analyzed data that is carried out before the processing of data analysis. The historical demand results or data have to present the demand in the same moments of time, in periods (hours, days, months, etc.) and in the same units (pieces, kilograms, tons, etc.). To verify the accuracy of the obtained forecasts, they can be checked by calculating the error that is shown by the chosen method.

However, in the real life applications there are tasks, which have historic demand information with very scarce amount of statistical values, e.g. retail of collection at a clothing store; analyzing gene expression in medicine or the influence of pharmaceuticals over a short period of time in pharmacology, etc. Small amount of historic information statistics is called short time series in computer science. The aim of this article is to determine whether tasks that are difficult to formalize, including the processing of short time series, can be solved using the classic time series handling methods. Based on the simple demand data, the present research determines the errors made by the proposed methods and provides assessment on the application of these methods.

\section{THE METHODS OF THE RESEARCH}

Short time series is defined as successive events that are ordered by specific time and observations [5]. The number of periods in short time series is not large and it is described by the equation $T=\left\{T_{1}, T_{2}, \ldots, T_{n}\right\}$. The analysis of short time series is performed to determine the structure of series and forecast the future values. The analysis process determines the structure of time series and patterns that include noisy, peak, seasonal and cyclic values. To perform the short time series data analysis, it is important to ensure the integrity of the studied objects. Based on the tasks, the most adequate data pre-processing approaches have to be chosen to prepare the initial data for the data analysis process[5].

\section{A. Moving Average Method}

Moving average method is used if the time series does not show a strong trend, and the demand data fluctuate around a certain mean value [4]. In this situation, the moving average method can be used for forecasting. The value that is used for forecasting is also called an adaptive average; the values are attributed to the end of the interval, compared to moving average in statistics where smoothing is directed towards the middle of the interval. In the process of forecasting, it is assumed that the adaptive mean value is the most probable of the possible values for the next period $P_{t}$. Then the moving 
average value is $M_{t}=P_{t+1}$ and it is calculated using the equation (1):

$$
M_{t}=\frac{\left(x_{t}+x_{t-1}+\ldots+x_{t-N+1}\right)}{N}
$$

\section{where}

$N$ - the length of the smoothing interval; $x_{t}-$ the demand over the period $t$.

When using moving average models, the forecast depends on the length of the smoothing interval. To determine the most appropriate length of the interval, it is necessary to calculate and evaluate the mean forecasting error for different intervals. For this reason, one can use mean absolute deviation, squared error, mean squared error or mean absolute percentage error [4].

The limitations of the moving average method are related to the requirement for large amount of historic statistics because, when they are smoothed, the average data are summed, decreasing the overall number of periods. This method is not recommended if the fluctuations of the historic data have large dispersion and if the nature of the fluctuations is seasonal, which would create unnecessary smoothing. To avoid one of the shortcomings of the moving average method, when there are unequal values between values in the periods of the time series, weights are used to smooth out the importance between periods. The value of weights is set by a user. The sum of all weights has to be equal to 1 .

\section{B. Exponential Smoothing}

Exponential smoothing is based on historical demand data, forecast of the preceding period and the calculation of its squared error [7]. This method uses weight correction that corrects the last demand in the historical time series. The forecast for the new period is calculated according to the equation (2):

$$
F_{t+1}=\alpha \cdot R_{t}+(1-\alpha) \cdot f_{t}
$$

where

$F_{t+1}$ - the forecast for the next period;

$0<\alpha<1-$ the constant of exponential smoothing;

$R_{t}$ - the actual demand of the previous period;

$f_{t}-$ the forecast of the previous period.

The forecast of the previous period is calculated as the mean of the previous periods. The constant of exponential smoothing $\alpha$ regulates the sensitivity towards demand fluctuations. If its value is too high, it is responsive to demand fluctuations, but if its value is too low, the model will be less responsive towards demand fluctuations. Therefore high values of $\alpha$ are used to forecast demand with short historical information, but low values of $\alpha$ are used to forecast large amount of statistical data. The correct choice of the constant value of exponential smoothing diminishes the squared error
$(S E)$ of the forecast that is calculated according to the equation (3):

$$
S E=\sqrt{\frac{\sum_{t=1}^{n}\left(F_{t}-R_{t}\right)^{2}}{n-1}},
$$

where

$F_{t}$ - the demand forecast in the $t$-th period;

$R_{t}$ - the actual demand in the $t$-th period;

$n$ - the number of periods in the time series.

However, the probability of forecast credibility should also be taken into account as it has a direct influence on the forecast error distribution based on the type of the chosen error distribution. Usually the normal error distribution type is chosen. In the normal distribution only approximately two percent of observations exceed two standard deviations above the average level. Whereas the error usually fluctuates close to the mean value, that follows from the assumption about the normal distribution, the actual forecast, regarding the chosen probability level in normal distribution, is calculated as shown in the equation (4):

$$
F F_{f}=t \pm z \cdot S E
$$

where

$F F_{t}$ - the demand forecast according to the chosen confidence level;

$t$ - the calculated short-time forecast for the next period;

$z$ - the number of standard deviations according to the chosen confidence level.

Therefore the probabilistic actual demand value at $95 \%$ confidence level is \pm 1.96 standard deviations, that conforms to normal distribution and varies in the interval $-z<F F_{t}<+z$. The value of standard value can be calculated with the help of guidebooks [4].

The advantage of the above-mentioned method is its ability to adapt itself to changes between periods with little historical information. The accuracy of the forecast depends on the chosen constant of exponential smoothing. If the changes between periods have low variations then a lower value should be chosen for the constant, but if the variations are large, the value of the constant should be larger.

\section{Exponential Smoothing with the Development Trend}

The method of exponential smoothing with the development trend is based on the sum of two equations that describe the short-time forecast $p_{t+1}$ and trend $T_{t+1}$ [8]. The short-time forecast is calculated as shown in the equation (5):

$$
p_{t+1}=\alpha \cdot R_{t}+(1-\alpha) \cdot\left(p_{t}+T_{t}\right)
$$

where

$p_{t}-$ the forecast for period $t$;

$0<\alpha<1$ - the constant of exponential smoothing;

$R_{t}$ - the actual demand of the previous period; 


$$
T_{t} \text { - the trend of changes in period } t \text {. }
$$

The trend is calculated according to the equation (6):

$$
T_{t+1}=\beta \cdot\left(p_{t+1}-p_{t}\right)+T_{t} \cdot(1-\beta),
$$

where

$$
\beta \text { - the trend smoothing constant in period } t \text {. }
$$

The trend smoothing constant $\beta$ is estimated, based on the assumption similar to exponential smoothing constant - the larger value is chosen to be $\beta$, the larger the influence of the short-time forecast will be and the smaller the impact of the trend will be.

The advantage of the exponential smoothing and exponential smoothing with the development trend methods is their ability to operatively calculate forecasts for the next period based on the previous period; but their disadvantage is the lack of information about forecasts after the calculated period because both methods are based on the actual value of the preceding periods and the comparison of their forecast error.

\section{THE EXPERIMENTS AND RESULT ANALYSIS}

In the experiments, the historical demand dataset (containing 65 records) has been used for a certain product group. Every record describes demand for the product in each month of the year. Based on this dataset, a total demand for the product group has been generated for each month of the year, see Fig. 1.

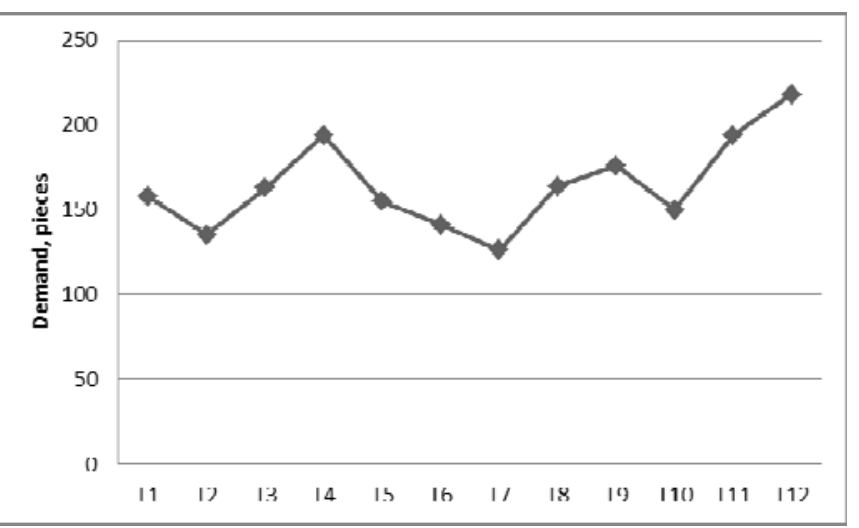

Fig. 1. Demand for the product group

As the basis of the moving average method, a smoothing interval of three to ten periods has been used; and, according to the calculated squared error, the most appropriate smoothing interval has been chosen.

Using exponential smoothing and exponential smoothing with trend adjustment method, the first six periods (T1-T6) have been used as a set of historical demands serving as the basis for forecast. The next six (T7-T12) have been compared to forecast the result, and the forecast error has been calculated.
In the experiments with the moving average method, using different smoothing period intervals, the obtained errors can be seen in Table I.

TABLE I

FORECAST USING DIFFERENT PERIOD SMOOTHING INTERVALS

\begin{tabular}{||c|c|c|c|c|c|c|c|c|c|c||}
\hline $\mathbf{N}$ & T3 & T4 & T5 & T6 & T7 & T8 & T9 & T10 & T11 & T12 \\
\hline 3 & 152 & 164 & 171 & 163 & 141 & 144 & 155 & 163 & 173 & 187 \\
\hline 4 & & 163 & 162 & 163 & 154 & 147 & 152 & 154 & 171 & 185 \\
\hline 5 & & & 161 & 158 & 156 & 156 & 152 & 151 & 162 & 180 \\
\hline 6 & & & & 158 & 152 & 157 & 159 & 152 & 159 & 171 \\
\hline 7 & & & & & 153 & 154 & 160 & 158 & 158 & 167 \\
\hline 8 & & & & & & 155 & 157 & 159 & 163 & 166 \\
\hline 9 & & & & & & & 157 & 156 & 163 & 169 \\
\hline 10 & & & & & & & & 156 & 160 & 168 \\
\hline
\end{tabular}

Using the exponential smoothing method, three different constant values $\alpha$ of exponential smoothing have been used; the obtained results are shown in Table II.

TABLE II

FORECAST WITH DIFFERENT EXPONENTIAL SMOOTHING CONSTANTS

\begin{tabular}{||c|c|c|c|c|c|c||}
\hline $\boldsymbol{\alpha}$ & T7 & T8 & T9 & T10 & T11 & T12 \\
\hline 02 & 155 & 149 & 152 & 157 & 156 & 164 \\
\hline 0.4 & 151 & 143 & 155 & 162 & 154 & 171 \\
\hline 0.8 & 144 & 132 & 161 & 171 & 151 & 186 \\
\hline
\end{tabular}

Using exponential smoothing with the development trend method, three different trend smoothing constants $\beta$ have been used; the forecasting results are presented in Table III.

TABLE III

FORECAST WITH DIFFERENT TREND SMOOTHING CONSTANTS

\begin{tabular}{||c|c|c|c|c|c|c|c||}
\hline $\boldsymbol{\alpha}$ & $\boldsymbol{\beta}$ & T7 & T8 & T9 & T10 & T11 & T12 \\
\hline 0.2 & 0.3 & 154 & 154 & 158 & 158 & 156 & 155 \\
\hline 0.4 & 0.5 & 148 & 144 & 148 & 149 & 144 & 147 \\
\hline 0.8 & 0.9 & 132 & 127 & 150 & 165 & 155 & 180 \\
\hline 0.2 & 0.9 & 152 & 165 & 167 & 162 & 167 & 154 \\
\hline 0.8 & 0.3 & 140 & 127 & 153 & 167 & 152 & 182 \\
\hline 0.1 & 0.3 & 156 & 160 & 165 & 167 & 170 & 169 \\
\hline 0.9 & 0.9 & 129 & 125 & 157 & 172 & 154 & 187 \\
\hline
\end{tabular}

Squared error has been calculated for all methods used in the experiments by means of different intervals and smoothing coefficients; the achieved results can be seen in Table IV.

TABLE IV

SQUARED ERROR OF FORECASTING

\begin{tabular}{||l|c|c|c|c||}
\hline \multicolumn{1}{|c|}{ Method } & $\mathbf{N}$ & $\boldsymbol{\alpha}$ & $\boldsymbol{\beta}$ & $\mathbf{S E}$ \\
\hline Moving average & 3 & & & 20.44 \\
\hline Moving average & 4 & & & 17.97 \\
\hline Moving average & 5 & & & 14.91 \\
\hline Moving average & 6 & & & 11.24 \\
\hline Moving average & 7 & & & 10.25 \\
\hline Moving average & $\mathbf{8}$ & & & $\mathbf{1 0 . 1 0}$ \\
\hline Moving average & 9 & & & 13.49 \\
\hline Moving average & 10 & & & 13.18 \\
\hline Exponential smoothing & & 0.2 & & 34.79 \\
\hline Exponential smoothing & & 0.4 & & 33.05 \\
\hline Exponential smoothing & & $\mathbf{0 . 8}$ & & $\mathbf{3 1 . 2 6}$ \\
\hline $\begin{array}{l}\text { Exponential smoothing with the } \\
\text { development trend }\end{array}$ & & 0.2 & 0.3 & 36.63 \\
\hline $\begin{array}{l}\text { Exponential smoothing with the } \\
\text { development trend }\end{array}$ & & 0.4 & 0.5 & 42.89 \\
\hline
\end{tabular}


TABLE IV (CONTINUED)

\begin{tabular}{||l|c|c|c|c||}
\hline \multicolumn{1}{|c|}{ Method } & $\mathbf{N}$ & $\boldsymbol{\alpha}$ & $\boldsymbol{\beta}$ & $\mathbf{S E}$ \\
\hline $\begin{array}{l}\text { Exponential smoothing with the } \\
\text { development trend }\end{array}$ & & 0.8 & 0.9 & 32.52 \\
\hline $\begin{array}{l}\text { Exponential smoothing with the } \\
\text { development trend }\end{array}$ & & 0.2 & 0.9 & 33.55 \\
\hline $\begin{array}{l}\text { Exponential smoothing with the } \\
\text { development trend }\end{array}$ & & 0.8 & 0.3 & 33.19 \\
\hline $\begin{array}{l}\text { Exponential smoothing with the } \\
\text { development trend }\end{array}$ & & $\mathbf{0 . 1}$ & $\mathbf{0 . 3}$ & $\mathbf{2 9 . 4 2}$ \\
\hline $\begin{array}{l}\text { Exponential smoothing with the } \\
\text { development trend }\end{array}$ & 0.9 & 0.9 & 31.25 \\
\hline \hline
\end{tabular}

The obtained results show that the best results are achieved using the moving average method with eight $(\mathrm{N}=8)$ period smoothing interval. The exponential smoothing method shows the best results, when the value of exponential smoothing constant is at its maximum. The exponential smoothing with the development trend shows the least error value with minimum and maximum values of the smoothing coefficients.

If we calculate demand forecast using the exponential smoothing method with the chosen confidence interval, the forecast for period $\mathrm{T} 12$ will be 169 , i.e., $F F_{t}=169$ $\pm 1,96 * 29,42$ (SE).

\section{CONCLUSIONS}

According to the conducted experiments, the moving average method (see Fig. 2) achieves the smallest squared error value, but the forecast smoothing regarding the initial historical data is too large. This indicates that forecasting results are too much smoothed and they do not reflect the actual demand. If the store uses this method to forecast the demand for goods in clothing retail, where the flow of goods is dictated by fashion - collections (usually two or four in a year), then smoothing that is too much expressed can cause

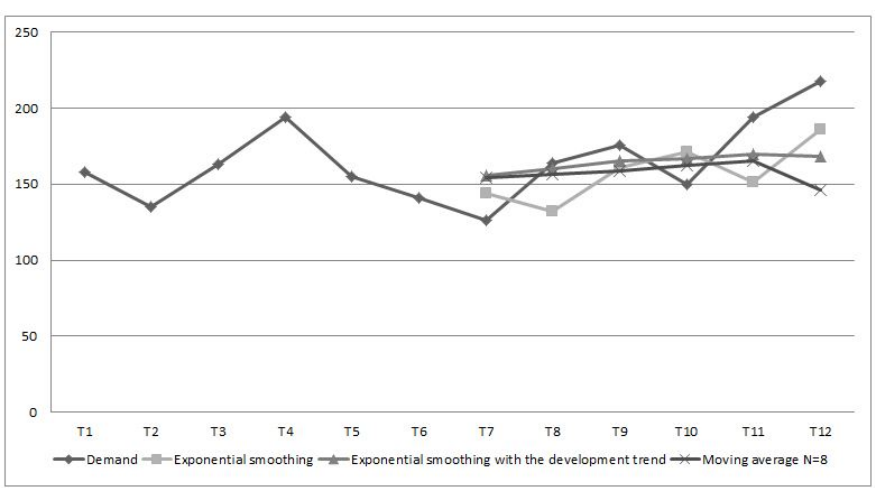

Fig. 2. Initial historical data and the obtained forecasts using the methods considered in the paper

either excess of the product or shortage in the market, which is unacceptable from the business point of view. Therefore, this method should not be used in short time series forecasting.

Similar results, also with too much smoothing for the forecasts, have been shown by exponential smoothing with the development trend. This method is also not recommended for use in short time series forecasting.
The exponential smoothing has shown the largest squared error value using the chosen dataset; the forecasting result curve of this method repeats the fluctuation of historical data. It means that theoretically this method can be used for short time series forecasting because it reacts to both sharp and slight changes in demand. This method can be used under the condition that there is at least little historical demand information (two to six periods). To decrease the value of squared error, values of the exponential smoothing $\alpha$ can be used by assigning different weights to different dynamic levels of the series. For example, if it is known that the forecast is influenced by the closest levels of the previous series, then value of $\alpha$ should be larger, but, if the main influence comes from the previous values, then value of $\alpha$ should be smaller. The sum of weights should be equal to 1 .

The dataset used in the experiments has been compiled from one product group. The given dataset reflects the overall demand for the products of one group over a specific period of time, but it does not analyze every product or time series separately (see Fig. 3). If each time series is analyzed separately, a lot of

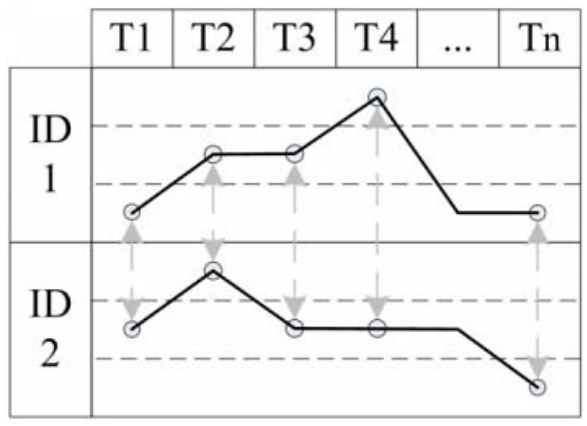

Fig. 3. Time series comparison for each period of time

significant information that influences the forecast directly is lost. For example, if we talk about clothing retail, where each historical demand time series has also descriptive information - size, colour, model etc., then in the analysis of the group this information is lost. To forecast demand for each product, it is necessary to carry out a deeper data analysis by comparing time series at each point of time. This type of analysis can be performed using data mining methods and algorithms by finding similarities in the time series and then grouping them according to similarity measures - clustering the data. Based on the patterns of the found groups, it is possible to make a connection between the historical demand of the product and its descriptive information, using data mining classification methods.

The research shows that in the processing of short time series, using the methods considered in this article, forecasting can be performed under the condition that there is no need for more detailed historical data analysis. The historical demand data series has to include information that does not hold more than one condition and it should not have any dependent descriptive parameters. 


\section{ACKNOWLEDGMENTS}

This research has been supported by the European Social Fund within the framework of the project "Support for the Implementation of Doctoral Studies at Riga Technical University".

\section{REFERENCES}

[1] J. J. Flores and R. Loaeza, Financial time series forecasting using a hybrid neural-evolutive approach, Proceedings of the XV SIGEF International Conference, Lugo, Spain, 2009, pp. 547-555.

[2] E. de Alba and M. Mendoza, Bayesian Forecasting Methods for Short Time Series, Foresight: The International Journal of Applied Forecasting, International Institute of Forecasters, Issue 8, 2007, pp. 41-44.

[3] J. S. Armstrong, F. Collopy and J. T. Yokum, Decomposition by causal forces: A procedure for forecasting complex time series, International Journal of Forecasting, 21, 2005, pp. 25-36.

[4] D. C. Montgomery, C. L. Jennings and M. Kulachi, Introduction to time series analysis and forecasting. Wiley-interscience, 2008.

[5] J. Ernst, G. J. Nau and Z. Bar-Joseph, Clustering short time series gene expression data, Bioinformatics, Vol. 21, No. suppl_1, 2005, pp. $159-168$.

[6] I. H. Written and E. Frank, Data mining: practical machine learning tools and techniques - $2^{\text {nd }}$ edition. Amsterdam etc.: Morgan Kaufman, 2005.

Arnis Kiršners, Arkadijs Borisovs. Īsu laika rindu apstrādes metožu salīdzinošā analīze

Rakstā tiek analizētas tradicionālās laika rindu apstrādes metodes, kuras tiek lietotas pieprasījumu prognozēšanai īsu laika rindu analīzei. Parasti, analizējot pieprasījuma datus, kuri tiek uzskatīti par laika rindām un attēlo kāda produkta vēsturisko pieprasījumu tirgū konkrētā laika vien̄̄bā, rodas prognozes nepieciešamība, lai noteiktu šī produkta iespējamo pieprasījumu nākotnē. Ar prognozes palīdzību, iespējams, samazināt lēmumu riskus, kas rodas, piemēram, pasūtot nepieciešamo produkta daudzumu nākamajam periodam. Tradicionāli laika rindu analīzes process tiek balstīts uz likumsakarību meklēšanu ilgākā laika posmā, analizējot vērtību izmainas laika momentos, tā rezultātā tiek noteiktas analizējamā objekta iespējamās vērtības nākotnē. Prognozes mērkis ir pēc iespējas efektīvāk samazināt nejaušu faktoru ietekmi uz gal̄̄go rezultātu, kā arī palīdzēt lēmējpersonai izvēlēties pareizo stratēgiju, pieṇemot lēmumu. Iegūto prognozes ticamību ir iespējams pārbaudīt, aprēkinot izvēlētās pieejas vai metodes radīto kḷūdu. Bet praksē ir sastopami uzdevumi, kad vēsturiskā pieprasījuma informācija ir pieejama ar ļoti nelielu statistikas daudzumu, piemēram, apgēerbu tirdzniecība ar kolekcijas precēm; medicīnā analizējot gēnu ekspresijas vai farmakolog̣ijā analizējot zāḷu iedarbību īsā laika vienībā utt. Rakstā ir analizētas eksponenciālās nogludināšanas, eksponenciālās nogludināšanas ar attīstības tendenci un slīdošā vidējā lieluma metodes. Aprakstīi šo metožu uzbūves un darbības principi. Raksta mērkis ir pārbaudīt šo metožu izmantošanas iespēju, analizējot īsas laika rindas. Eksperimentāli veikti pētījumi, izmantojot reālus pieprasījuma datus. Izvērtēti iegūtie rezultāti un sniegti ieteikumi par šo metožu izmantošanu īsu laika rindu analīzē.

\section{Арнис Киршнерс, Аркадий Борисов. Сравнительный анализ методов обработки коротких временных рядов}

В статье анализируются традиционные методы обработки временных рядов, которые используются в задачах прогнозирования спроса для анализа коротких временных рядов. Как правило, анализируя данные спроса, которые рассматриваются в качестве временных рядов и представляют собой исторический спрос продукта в определенной единице времени, появляется необходимость прогноза, чтобы определить потенциальный спрос на этот продукт в будущем. Прогноз помогает снизить риски принятия решения, возникающие, например, при заказе необходимого количества продуктов на следующий период. Традиционно, анализ временных рядов основан на процессе поиска закономерностей в долгосрочном периоде, анализируя изменения значения в определенном моменте времени, в результате чего определяется прогноз в будущем. Цель прогноза - эффективно снизить влияние случайных факторов на конечный результат, а также помочь лицу, принимающему решение, выбрать правильную стратегию для принятия решения. Достоверность прогноза определяется при расчёте ошибки подхода или метода. Но на практике встречаются задачи, в которых историческая информация о спросе доступна с очень небольшим количеством статистических данных, это, например, торговля коллекционной одеждой, в медицине - анализ экспрессии генов, в фармакологии - анализ воздействия препарата в коротком временном интервале и т.д. В данной статье анализируются методы экспоненциального сглаживания, экспоненциального сглаживания с тенденциями развития и скользящего среднего. Описано построение и принципы работы этих методов. Целью статьи является проверка возможности применения этих методов, анализируя короткие временные ряды. Проведены исследования с использованием реальных данных спроса. Оценены результаты и предложены рекомендации по применению этих методов в анализе коротких временных рядов. 